\title{
Blood Flow Restriction Rehabilitation
}

\author{
Dhivagar Subbarayan ${ }^{1}$, Santhiya Veerappana ${ }^{2}$
}

\begin{abstract}
Blood flow restriction (BFR) training is an aerobic exercise is performed by using a tourniquet, which is applied to the proximal aspect of the muscle. In this unique method, limb blood flow is restricted by using a cuff throughout the contraction cycle and rest period. It is highly effective shown by partial restriction of arterial inflow to muscle, but it restricts venous outflow from the muscle. It produces less load nature and strengthening capacity of muscles by using BFR training. It can provide an effective clinical rehabilitation stimulus without the high levels of stress and circulatory system risk associated with heavy-load training. BRF can reduce the loss of muscle mass and increase the bony healing process during the early immobilization of patients. It improves both muscle size and strengthening the muscles without stress of heavy lifts on soft tissue healing. Blood flow restriction rehabilitation is a safest and effective method to improve the muscle strength among patients who are unable to perform high-resistance exercise.

Keywords: Blood flow restriction training, Occlusion training, Rehabilitation.

Pondicherry Journal of Nursing (2019): 10.5005/jp-journals-10084-12105
\end{abstract}

\section{INTRODUCTION}

Blood flow restriction rehabilitation (BFRR) is a unique and significant way to rehabilitate muscle injuries, especially those who underwent orthopedic surgeries. The restriction of venous outflow among the extremity during decreased load resistance exercises is a safe and effective method for the patients to strengthen their muscles. ${ }^{1,11}$

\section{Historical View}

Blood flow restriction therapy was firstly originated in Japan in 1966 historically is called as KAATSU training. KA means "additional" and ATSU means "Pressure". It is proven by the significant research, intensive protocols, and patented procedures in sports, exercise, and rehabilitation, and wellness supports KAATSU training's effectiveness. ${ }^{2,13}$

\section{What is Blood Flow Restriction Rehabilitation?}

In BFR training, a person works out by using narrow, elastic band around the upper part of the arm or leg. The methods of banding will help in partial restriction of venous blood flow and it never affects the arterial inflow to the extremity. ${ }^{1,10}$ Repetition of a particular exercise by using this elastic band will help the person to strengthening the muscles; while person lifts heavy weights it will reduce the stress to muscle tissues that may help to improve the healing process of recent injury or surgery. ${ }^{3,14}$

\section{How Does it Works?}

This is a noninvasive procedure; hence the elastic cuff is placed on the injured arm or leg to gradually reduce blood flow to the extremity during specific exercise. The process of limiting the blood flow to the muscles is called occlusion; BFR is otherwise called occlusion therapy. It helps to facilitate the person to workout the muscles without placing more weight on the extremity. BFR focuses the person to activate all muscles of the limb while the blood flow is restricted. It can be incorporated into traditional physical therapy. BFR is a part of rehabilitation efforts. Follow-up of anterior cruciate ligament $(A C L)$ surgery appears to preserve the bone recovering muscle loss and strengthened the
${ }^{1}$ Department of Mental Health Nursing, Kasturba Gandhi Nursing College, Sri Balaji Vidyapeeth, Puducherry, India

${ }^{2}$ Department of Mental Health Nursing, Sri Manakula Vinayakar Nursing College, Puducherry, India

Corresponding Author: Dhivagar Subbarayan, Department of Mental Health Nursing, Kasturba Gandhi Nursing College, Sri Balaji Vidyapeeth, Puducherry, India, Phone: +91 8754733698, e-mail: dhivagalaxy@ gmail.com

How to cite this article: Subbarayan D, Veerappana S. Blood Flow Restriction Rehabilitation. Pon J Nurs 2019;12(1):28-30.

Source of support: Nil

Conflict of interest: None

bones and improve fast muscle function. ${ }^{9}$ BFR is a perfect additive therapy for ACL patients for the purpose of reducing the loss and fasten the recovery of muscle, bone, and physiological function. ${ }^{2,12,20}$

\section{Who Benefits?}

BFR training is accessed for regular fitness, and also useful for patients in initial phase of rehabilitation during limb surgeries. It includes $A C L$ reconstructions, meniscectomy, hip/knee replacements, rotator cuff repair or tendon repair surgeries. $4,15,30$

Research evidences showed that, BRF could reduce the loss of muscle mass and increase the bony healing process during the early immobilization of patients. It improves both muscle size and strengthening the muscles without stress of heavy lifts on soft tissue healing. ${ }^{3}$ Persons with osteopenia, rheumatoid arthritis, osteoarthritis, etc. may also exclusively benefited from BFR training and also it is highly recommended for patient with spinal cord injuries or strokes. ${ }^{3,14}$

\section{Is BFR Safe?}

Traditional research evidences have shown that BFR not only provides comfort to the patients, but also it is safest and effective method of training while performing certain exercise appropriately. Trained blood flow restriction professionals will monitor the equipment continuously. 
- Clot risk is minimal in BFR

- No evidences of damaging the blood vessels and cardiac muscles

- During BFR training the targeted limb occlusion pressure of the equipment is maintained under the pressure of $40-80 \%$ and is safe and effective. Therefore, Its lower pressure may provide less risk to reduce the need for higher pressure. Risk factors of BFR such as improper tourniquet width, excessive tourniquet pressure and improper placement of tourniquet will lead to muscle injury and it can cautiously seen in safety system measures. ${ }^{5,17}$

\section{BRF DeVICE}

Gold standard blood flow restriction device formulated by Delphi Personal Tourniquet System from Owens Recovery Science. Food and Drug Administration (FDA) approved this device. It contains a Doppler ultrasound with blood flow restriction cuff and gives most accurate way to measure blood flow in the limbs and safely occludes the appropriate blood flow (Fig. 1). 3,16,29

\section{Cuff Width and Material}

- Cuff width and material is significant to determine the successful completion of BFR.

- While measuring blood pressure, accurate prefixed pressure is essential.

- Narrow cuffs are totally blocked by blood flow, so these are best to be avoided. Using of wide cuff will provide comfort to the patients. Research evidences coats range of $3-5 \mathrm{~cm}$ width cuffs is very useful.

- Nylon cuff materials or a regular blood pressure measuring cuffs are safe and most effective. ${ }^{6}$ In arterial occlusion pressure, limb circumference is next factor that affects the muscles. A large extremity requires higher cuff pressure to occlude than a smaller extremity to maintain appropriate pressure. ${ }^{7,19,28}$

\section{Cuff Placement}

The placement of cuff should be as high as possible on affected limbs. For the upper extremity, the cuff should be placed as proximal on the biceps area. For the lower extremity, cuff is place just below the gluteal fold. If the cuff is too loose and low placement, we cannot achieve optimal occlusion, thereby effectives of BFR will reduced. ${ }^{21}$

\section{Duration of BFR}

- Blood flow restriction therapy differs from each individual's muscle strength. Based on the patient needs, duration has been

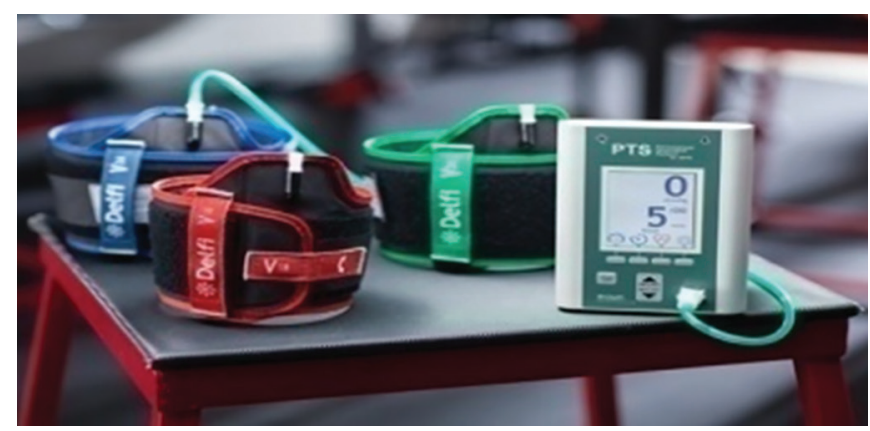

Fig. 1: Blood flow restriction apparatus determined; the duration of exercise is 1 or 2 session per day from 4 to 7 days per week.

- The initiation of BFR postoperatively ranges from postoperative surgery such as day 1-2 weeks. ${ }^{9}$

\section{Types of Exercise under BFR}

- The range of exercise starts from isolated joint to total extremity

- Different types of muscle contractions

- Combination of the concentric/eccentric exercises ${ }^{6,18,27}$

\section{Benefits of BFR in Elderly}

- Muscle mass will be improved

- Increase the muscle strength

- Normalized the cardiovascular status

- Increase the positive bone density and increased functional outcomes

- Self efficacy improved ${ }^{8}$

\section{Results with BFR}

Blood flow restriction rehabilitation is a highly recommended for patient with orthopedic surgeries and is an injury recovery therapy that is producing dramatically positive results to the healing process.

- Reduce the loss of strength and atrophy of the muscles and non-weight bearing during post injuries

- $30 \%$ loads will increase strength and reduce hypertrophy

- Improved muscle endurances in 1/3 the time

- Improved muscle protein synthesis among elder individuals

- Improved muscle activation

- Increased growth hormones responses, it increases collagen synthesis

- Important for the tissue regeneration phase after injury.,24,27

\section{Risk Associated with BFR}

Rhabdomyolysis cases have been identified while using narrow belts and lifting straps of tourniquet; the amount of pressure on the vasculature was unable to be controlled. ${ }^{3,23,25}$

\section{Relative Contraindication-BFR}

- Shiny or scaly skin and varicose veins

- Venous thromboembolism

- Infected extremity

- Vascular grafting process

- Open fracture

- Lymphectomies

- Clinically diagnosed cancer ${ }^{7,22,26}$

\section{Conclusion}

Blood flow restriction rehabilitation is a safest and effective method to improve the muscle strength among patients who are unable to perform high-resistance exercise and patients who have persistent weakness of the extremity will have despite traditional therapy.

\section{References}

1. Pope ZK, Willardon JM, Schoenfeld B. A brief review: exercise and blood flow restriction. Eur J Appl Phys 2013;23:1708-1713. 
2. Abe T, Kearns CF, Manso Filho HC, Sato Y, McKeever KH. Muscle, tendon and somatotrophin responses to the restriction of muscle blood flow induced by KAATSU walk training. Equine Vet J Suppl 2006;161:345-348. DOI: 10.1111/j.2042-3306.2006.tb05566.x.

3. Burgomaster KA, Moore DR, Schofield LM, Phillips SM, Sale DG, Gibala MJ. Resistance training with vascular occlusion: metabolic adaptations in human muscle. Med Sci Sports Exerc 35(7):1203-1208. DOI: 10.1249/01.MSS.0000074458.71025.71.

4. Esco MR. Resistance training for health and fitness, American college of sports Medicine Consumer information, 2013, acsm.org.

5. Loeneke JP. Effects of low-intensity walk training with restricted leg blood flow on muscle strength and aerobic capacity in older adults. J Geriatr Phys Ther 2010;11:33-40.

6. Gualano B, Neves Jr M, Lima FR, Pinto AL, Laurentino G, Borges C, et al. Resistance training with vascular occlusion in inclusion body myositis: a case study. Med Sci Sports Exerc 2010;42:250-254. DOI: 10.1249/MSS.0b013e3181b18fb8.

7. Paulos L, Noyes FR, Grood E, Butler DL. Effect of BFRT after anterior cruciate ligament reconstruction and repair. J Orthop Sports Phys Ther 1991;13:60-70. DOI: 10.2519/jospt.1991.13.2.60.

8. Scott BR, Loenneke JP, Slattery KM, Dascombe BJ. Exercise with blood flow restriction, an updated evidence-based approach for enhanced muscular develop-ment. Sports Med 2015;45(3):313-325. DOI: 10.1007/ s40279-014-0288-1.

9. Dinenno FA, Jones PP, Seals DR, Tanaka H. Limb blood flow and vascular conductance are reduced with age in healthy humans: relation to elevations in sympathetic nerve activity and declines in oxygen demand. Circulation 1999 Jul 13;100(2):164-170.

10. Woolf AD, Pfleger B. Burden of major musculoskeletal conditions. Bull World Health Organ 2003;81:646-656.

11. Blain H, Vuillemin A, Teissier A, Hanesse B, Guillemin F, Jeandel C. Influence of muscle strength and body weight and composition on regional bone mineral density in healthy women aged 60 years and over. Gerontology 2001;47:207-212. DOI: 10.1159/000052800.

12. Loenneke JP, Kim D, Fahs CA, Thiebaud RS, Abe T, Larson RD. Effects of exercise with and without different degrees of blood flow restriction on torque and muscle activation. Muscle Nerve 2015;51:713-721. DOI: 10.1002/mus.24448.

13. Takarada Y, Takazawa H, Sato Y, Takebayashi S, Tanaka Y, Ishii N. Effects of resistance exercise combined with moderate vascular occlusion on muscular function in humans. J Appl Phys 2000;88:2097-2106. DOI: 10.1152/jappl.2000.88.6.2097.

14. Loenneke JP, Wilson JM, Marín PJ, Zourdos MC, Bemben MG. Low intensity blood flow restriction training: a meta-analysis. Eur J Appl Physiol 2012;112:1849-1859. DOI: 10.1007/s00421-011-2167-x.

15. Pearson SJ, Hussain SR. A review on the mechanisms of blood-flow restriction resistance training-induced muscle hypertrophy. Sports Med 2015;45:187-200. DOI: 10.1007/s40279-014-0264-9.

16. Takarada Y, Nakamura Y, Aruga S, Onda T, Miyazaki S, Ishii N. Rapid increase in plasma growth hormone after low-intensity resistance exercise with vascular occlusion. J Appl Physiol 2000;88:61-65. DOI: 10.1152/jappl.2000.88.1.61
17. Loenneke JP, Fahs CA, Rossow LM, Abe T, Bemben MG. The anabolic benefits of venous blood flow restriction training may be induced by muscle cell swelling. Med Hypotheses 2012;78:151-154. DOI: 10.1016/ j.mehy.2011.10.014.

18. Fujita S, Abe T, Drummond MJ, Cadenas JG, Dreyer HC, Sato Y. Blood flow restriction during low-intensity resistance exercise increases S6K1 phosphorylation and muscle protein synthesis. J Appl Physiol 2007;103:903-910. DOI: 10.1152/japplphysiol.00195.2007.

19. Fry CS, Glynn EL, Drummond MJ, Timmerman KL, Fujita S, Abe T, et al. Blood flow restriction exercise stimulates mTORC1 signaling and muscle protein synthesis in older men. J Appl Physiol 2010;108: 1199-1209. DOI: 10.1152/japplphysiol.01266.2009.

20. Segal NA, Williams GN, Davis MC, Wallace RB, Mikesky AE. Efficacy of blood flow restricted, low-load resistance training in women with risk factors for symptomatic knee osteoarthritis. PM R 2015;7:376-384. DOI: 10.1016/j.pmrj.2014.09.014.

21. Loenneke JP, Fahs CA, Rossow LM, Sherk VD, Thiebaud RS, Abe T. Effects of cuff width on arterial occlusion: implications for blood flow restricted exercise. Eur J Appl Physiol 2012;112:2903-2912. DOI: 10.1007/s00421-011-2266-8.

22. Scott BR, Loenneke JP, Slattery KM, Dascombe BJ. Exercise with blood flow restriction: an updated evidence-based approach for enhanced muscular development. Sports Med 2015;45:313-325. DOI: 10.1007/ s40279-014-0288-1.

23. Higgins JPT, Green S. Cochrane handbook for systematic reviews of interventions. Chichester: Wiley Blackwell; 2008.

24. Segal N, Davis MD, Mikesky AE. Efficacy of blood flow-restricted low-load resistance training for quadriceps strengthening in men at risk of symptomatic knee osteoarthritis. Geriatr Orthop Surg Rehabil 2015;6:160-167. DOI: 10.1177/2151458515583088.

25. Iversen $\mathrm{E}$, Røstad V, Larmo A. Intermittent blood flow restriction does not reduce atrophy following anterior cruciate ligament reconstruction. J Sport Health Sci 2016;5:115-118. DOI: 10.1016/ j.jshs.2014.12.005.

26. Patterson SD, Ferguson RA. Enhancing strength and postocclusive calf blood flow in older people with training with blood-flow restriction. J Aging Phys Act 2011;19:201-213.

27. lida H, Nakajima T, Kurano M, Yasuda T, Sakamaki M, Sato Y. Effects of walking with blood flow restriction on limb venous compliance in elderly subjects. Clin Physiol Funct Imaging 2011;31:472-476. DOI: 10.1111/j.1475-097X.2011.01044.x.

28. Libardi CA, Chacon-Mikahil MP, Cavaglieri CR, Tricoli V, Roschel $H$, Vechin FC, et al. Effect of concurrent training with blood flow restriction in the elderly. Int J Sports Med 2015;36:395-399. DOI: 10.1055/s-0034-1390496.

29. Heitkamp HC. Training with blood flow restriction. Mechanisms, gain in strength and safety. J Sports Med Phys Fitness 2015;55: 446-456.

30. Jessee MB, Buckner SL, Mouser JG, Mattocks KT, Loenneke JP. Letter to the editor: Applying the blood flow restriction pressure: the elephant in the room. Am J Physiol Heart Circ Physiol 2016;310: H132-H133. DOI: 10.1152/ajpheart.00820.2015. 